never very severe. By Dec. 26th the abdowen was so distended with fluid and the breathing had become so embarrassed that paracentesis was performed and ten pints of yellow milk-like fluid were removed, but without any very great relief, and the man died six days later.

The fluid removed was yellow in colour and of a milk-like character; it had a specific gravity of 1018 and gave an alkaline reaction. On standıng a pinkish gelatinous clot was formed. Microscopically the fluid showed the presence of a large amount of fat in the form of an emulsion and also numerous cells containing fat in their interior. When shaken up with ether, fat was dissolved out and the ether left a greasy stain when dropped on paper.

At the necropsy, when the abdomen was opened, three pints of milky-looking fluid were found in the peritoneal cavity. There was no peritonitis. The glands in the mesentery were welded together with new growth and there was a large mass of growth behind the stomach almost encircling the aorta. The liver, together with some masses of glands, weighed 13 pounds. It was full of firm growths in the form of rounded lumps rising to the size of Tangerine oranges. On the surface they were slightly cupped from contraction. There was very little liver substance left uninvaded by growths. The left pleural cavity was half full of chyliform fluid similar to that in the abdomen. The right pleural cavity contained a similar amount of clear serum. With regard to the fluid in the abdomen, no special leakage could be discovered, but the receptaculum chyli and thoracic duct must have been implicated by growth which was very extensive in front of the first and second lumbar vertebræ. No special cause could be found to account for the milk-like fluid in the left pleura. Microscopically the growth was a spheroidal-celled carcinoma. Leicester.

\section{dittirtor OF}

\section{HOS PITAL PRACTICE, BRITISH AND FOREIGN.}

Nulla autem est alia pro certo noscendi via, nisi quamplurimas et morborum et dissectionum historias, tum aliorum tum proprias collectas habere, et inter
Morb., lib. v., Procmium.

\section{BATH ROYAL UNITED HOSPITAL.}

A CASE OF AOUTE ENTERIC INTUSSUSCEPTION CAUSED BY THE INVAGINATION OF MECKEL'S DIVERTICULUM OPERATION ; RECOVERY.

(Under the care of Mr. H. G. TERRY.)

For the notes of the case we are indebted to Mr. J. Beattie Dunlop, house surgeon.

A schoolboy, aged 12 years, was admitted into the Bath Royal United $H$ sspital on Dec. 16th, 1902, at about 9 P.M. The history of the case was that the boy had been quite well on that day until noon when he made a hearty dinner, but during it was seized with some abdominal discomfort. He returned to school at 1.30 P.M., but while there he had such severe attacks of pain in his abdomen that he was sent home. Here his pain was thought to be due to indigestion and he was given peppermint water. As his condition did not improve Mr. E. L. Hunt, of Sherston, was sent for and he arrived about 4 P.M. He found the boy crying from pain and rolling from side to side. The patient's temperature was $96.5^{\circ} \mathrm{F}$. and his pulse was 60 . His pain was found to be most acute below and to the right of the umbilicus and there a sausageshaped tumour could be palpated three or four inches long and running up towards the liver. He had been vomiting partially digested food and had passed a loose watery motion containing blood. Mr. Hunt diagnosed acute intussusception and sent him straightway to hospital-a drive of over 18 miles.

On admission the boy's facies was not anxious. From time to time he had bouts of pain which were referred to the region below and to the right of the umbilicus. His temperature was $99^{\circ}$ and his pulse was 60 and small in volume. The abdominal wall was slack and moved with respiration. There was very little distension. On palpation a sausage-shaped tumour was to be felt extending from the right iliac fossa to the right subcostal margin. It was firm, moveable, growing harder during the paroxysms of pain, and varying in size from time to time. Manipulation tended to make it smaller. Per rectum a tense swelling could be found in the right iliac fossa. Mr. Hunt's diagnosis was corroborated and operation was decided on at once.

The abdomen was accordingly opened to the right of the median line by Mr. Terry and an intussusception of the ileum forthwith presented itself. The tumour was 12 inches in length; it was tense, shining, cherry-red in colour, and the mesentery was twisted. Reduction was effected gradually and it was then seen that the intussusceptum was black in colour and that there was free fluid between the middle and internal layers. The blackness was dispelled gradually as reduction proceeded. At the end of the reduction, however, the apex of the intussusceptum gave way and was then found to consist of Meckel's diverticulum. The diverticulum was almost six inches in length and was swollen to the diameter of the small bowel, invaginated, and sloughing. Its invagination had evidently caused the intussusception of the ileum. This troublesome appendage was thereupon amputated at its junction with the bowel and the edges of the opening thus left were brought together by means of two layers of Lembert's sutures. The abdomen was then sewn up layer by layer. The boy bore the operation exceedingly well. On the next day he passed blood and llatus three times, and thenceforth made steady progreas, his recovery, how ever, being somewhat delayed by the skin giving way, though the rest of the abdominal wall held well. He was discharged cured on Feb. 6th.

Remarks by $\mathbb{M} x$. DUNLOP. - The above case is of interest from its bearing on the etiology of enteric intussusception. I must express my thanks to Mr. Terry for his kind permission to record this case, and to Mr. Hunt for the exceedingly good history which he sent us of it.

\section{dededical Societies.}

\section{CLINICAL SOCIETY OF LONDON.}

\section{Acromegaly.-Bulharziosis.-Surgical Treatment of Gan- grenous Bomel in Herniotomy.}

A MEETRG of this society was held on March 27th, Mr. How ARD MARSH, the President, being in the chair.

Dr. H. A. LeviARD (Carlisle) read a paper on a case of Acromegaly and Goitre. The patient was a woman, aged 43 years, who was born and had always lived in Cumberland. She had had amenorrhoea and headache dating from the last confinement, ten years previously. The features were characteristic, especially the lips, nose, lower jaw, and tongue, as were also the speech and expression of the face. The thorax was large, the ribs being massive and the hands being broadened. Sugar had been at one time present in the urine. For some years a bilateral goitre had been evident, but in June, 1902, the patient was sent to the Cumberland Infirmary for operation on account of dyspncea with stridor and dysphagia due to pressure. The left side of the goitre was then removed and all these symptoms were relieved. The patient was exhibited to the society and her feeble muscular power was demonstrated. Radiographs of the hands and other parts were exhibited, together with the goitre which had been removed and microscopic slides. The usual features of acromegaly not present in this case were kyphosis, bi-temporal hemianopsia, sweating, and cyanosis. There was no trace of the general increase in size sometimes present, but the features of the face and the limbs were so greatly enlarged that the patient could not be recognised by her relatives and the muscular power was feeble.-Dr. W. PAśteun asked whether the operation had in any way modified the character of the acromegalic condition.-Dr. LEDIARD, in reply, stated that there had been no change in the pulse or temperature since the operation, but the patient had gained several pounds in weight.

Dr. AXDREW DUNCAN read the notes of a case of Bilharziosis. The patient was a man, aged 30 years, lately in the 2nd Battalion East Fent Regiment. He had been fighting in the Orange River and Cape Colonies and was in Lord Roberts's march to Pretoria. In May, 1902, he began to experience 